Mariola NYCZ ${ }^{1}$

Miroslaw ŚMIESZEK ${ }^{2}$

\title{
WIELKOŚĆ PRZEWOZÓW PASAŻERSKICH W RELACJI DO WSKAŹNIKA MOTORYZACJI W WYBRANYCH KRAJACH UNII EUROPEJSKIEJ W LATACH 2008-2013
}

\begin{abstract}
Złożony i wielopłaszczyznowy system gospodarczy obecnego świata jest niezwykle sensytywnym układem kolektywnych powiązań funkcjonalnych i systemowych. W efekcie skutki kryzysu ekonomicznego są odczuwalne $\mathrm{w}$ różnych rejonach świata i sektorach gospodarczej działalności człowieka. Monitorowanie zmian zachodzących w gospodarce, szczególnie podczas kryzysu, jest istotne w zidentyfikowaniu przyczyn jego powstania, a w kolejnym etapie -odszukaniu rozwiązań umożliwiających efektywne złagodzenie konsekwencji jego wystąpienia. Współczesne społeczeństwa dążą do coraz większej mobilności, a celem polityki Unii Europejskiej jest kształtowanie i wspieranie efektywnych, bezpiecznych i zrównoważonych rozwiązań mających ją zapewnić. Ogromne znaczenie dla transportu odgrywają przewozy pasażerskie, które wskazują na potrzeby transportowe, odzwierciedlając przy tym dobrobyt społeczeństwa i kondycję gospodarczą państwa. W pracy porównano wielkości wykonanej pracy przewozowej w pasażerskim transporcie drogowym i kolejowym oraz liczbę przewiezionych pasażerów transportem lotniczym. Do analizy wybrano także zmienną będącą liczbą zarejestrowanych samochodów osobowych przypadających na tysiąc mieszkańców w wybranych krajach Unii Europejskiej. Analiza ma na celu wskazanie: zróżnicowania między przewozami pasażerskimi różnymi środkami transportu oraz ocenę wpływu kryzysu ekonomicznego z 2008 r. na wielkość analizowanych przewozów w UE. Celem dodatkowym przeprowadzonych badań było przedstawienie pozycji Polski na tle innych krajów, a także wskazanie relacji wzrostu liczby zarejestrowanych samochodów osobowych do wielkości przewozów pasażerskich. Publikacja powstała na podstawie danych prezentowanych przez Eurostat i OECD.

Słowa kluczowe: kryzys gospodarczy, transport pasażerski, wskaźnik motoryzacji.
\end{abstract}

\section{WPROWADZENIE}

Dokonując charakterystyki rynku usług transportowych jako procesu, należy podkreślić przede wszystkim jego niejednorodność, strukturalne przeobrażenia i dynamikę rozwoju, a także przebieg oraz zakres przyczynowo-skutkowy zdarzeń i zachowań jego uczestników³.

\footnotetext{
${ }^{1}$ Mgr Mariola Nycz, Katedra Metod Ilościowych, Wydział Zarządzania, Politechnika Rzeszowska im. I. Łukasiewicza, Al. Powstańców Warszawy 8, 35-959 Rzeszów, autor korespondencyjny, e-mail: m_nycz@prz.edu.pl

${ }^{2} \mathrm{Dr}$ hab. inż. Mirosław Śmieszek, prof. PRz, Katedra Metod Ilościowych, Wydział Zarządzania, Politechnika Rzeszowska im. I. Łukasiewicza, Al. Powstańców Warszawy 8, 35-959 Rzeszów, e-mail: msmieszk@prz.edu.pl

${ }^{3}$ Polski rynek usług transportowych. Funkcjonowanie - przemiany-rozwój, red. D. Rucińska, Warszawa 2012, s.17.
} 
$\mathrm{Z}$ punktu widzenia ekonomii transport spełnia trzy zasadnicze funkcje: konsumpcyjną (związana $\mathrm{z}$ zaspokojeniem potrzeb przewozowych), produkcyjną (umożliwia zaspokojenie zapotrzebowania na materiały i dostarczenie produktów do odbiorów pośrednich i bezpośrednich) oraz integracyjną (pozwalającą na powstanie i utrzymanie pewnych więzi zarówno w społeczności globalnej i regionalnej, jak i przez rozbudowę i stałość kontaktów gospodarczych). Należy także podkreślić, że transport nie może zostać zastąpiony przez żaden inny dział gospodarki. W procesie ekonomicznym rolę transportu determinują tempo i wielkość przyrostu zapotrzebowania na usługi transportowe ( $w$ tym na stopień aktywizacji społeczeństwa czy rozmiar i strukturę potencjału produkcyjnego $)^{4}$.

Potrzeby transportowe można traktować jako odzwierciedlenie dobrobytu społecznego oraz aktualnej kondycji gospodarczej państwa ${ }^{5}$.Każde zmiany koniunktury w gospodarce mają swoje odzwierciedlenie $\mathrm{w}$ funkcjonowaniu transportu, dlatego wspólna polityka transportowa jest istotnym punktem w polityce społeczno-gospodarczej Unii Europejskiej.

Przedmiotem analizy jest poziom przewozów pasażerskich i wykonanej pracy przewozowej w transporcie kolejowym, drogowym i lotniczym w latach 2005-2013 w wybranych krajach Unii Europejskiej. Do celów analitycznych wykorzystano cztery wielkości: przewozy pasażerów transportem lotniczym, mogące stanowić o zamożności (poziomie życia) wśród mieszkańców krajów europejskich, praca przewozowa wykonana w ramach drogowego i kolejowego transportu osób oraz wskaźnik zmotoryzowania społeczeństwa. Dane pochodzą z baz Eurostatu.

Celem pracy jest uzyskanie odpowiedzi na pytania:

- jak kryzys ekonomiczny z 2008 r. wpłynął na wielkość przewozów pasażerskich w analizowanych krajach Unii Europejskiej dla wybranych gałęzi transportu w późniejszych latach;

- czy można mówić o przestrzennym zróżnicowaniu oddziaływania kryzysu na funkcjonowanie transportu;

- czy istnieje zależność między poziomem zmian w przewozach pasażerskich a liczbą zarejestrowanych samochodów osobowych w krajach UE.

\section{ZMIANY PRZEWOZÓW W PASAŻERSKIM TRANSPORCIE DROGOWYM}

W pasażerskim transporcie drogowym popyt na przewozy będzie kształtował się inaczej niż w przypadku przewozów towarowych. Analizą objęto krajowe przewozy pasażerskie. Realny popyt, czyli realne zainteresowanie możliwościami skorzystania z oferty przewozowej, wynika przede wszystkim z: umiejscowieniu dużych zakładów pracy oraz ośrodków nauki i szkolnictwa, uwarunkowań osadnictwa czy lokalizacji centrum handlowych ${ }^{6}$.

Jednostkową miarą wykonanej pracy przewozowej przez środki transportu publicznego jest pasażerokilometr. Miara ta jest stosowana zarówno do opisu publicznego, jak

\footnotetext{
${ }^{4}$ E. Januła, Podstawy transportu i spedycji. A. 28. Organizacja i nadzorowanie transportu. 1. Planowanie realizacji procesów transportowych, Warszawa 2014, s. 93-94.

${ }^{5} \mathrm{~B}$. Grad, R. Krajewska, Wplyw kryzysu na przewozy pasażerów transportem kolejowym $w$ krajach Unii Europejskiej,„Logistyka” 2011/3, s. 765-766.

${ }^{6}$ M. Hajdul, M. Stajniak, M. Foltyński, A. Koliński, P. Andrzejczyk, Organizacja i monitorowanie procesów transportowych, Poznań 2015, s. 56.
} 
Wielkość przewozów...

i regularnego transportu pasażerskiego. W 2013 r. wykonano pracę przewozową na poziomie 356 mln pasażerokilometrów w skali państw europejskich, co stanowi spadek o 4\% w stosunku do roku 2005. W tablicy 1 przedstawiono dynamikę zmian w latach 2005-2013 w krajowym transporcie drogowym pasażerów.

Tabl. 1. Dynamika zmian wykonanej pracy przewozowej w pasażerskim transporcie drogowym w latach 2005-2013 wyrażona w pasażerokilometrach

\begin{tabular}{|c|c|c|c|c|c|c|c|c|c|c|}
\hline KRAJ & 2005 & 2006 & 2007 & 2008 & 2009 & 2010 & 2011 & 2012 & 2013 & Wykres zmienności \\
\hline Bulgaria & 100,0 & 98,0 & 99,3 & 100,1 & 82,0 & 80,8 & 79,5 & 75,1 & 72,6 & ㅁㅁㅁㅁ--ー- \\
\hline Belgia & 100,0 & 103,0 & 106,8 & 100,4 & 100,5 & 99,1 & 100,7 & 102,1 & 102,1 & 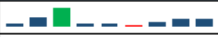 \\
\hline Czechy & 100,0 & 110,4 & 110,6 & 108,8 & 110,3 & 125,7 & 107,7 & 104,7 & 104,5 & - \\
\hline Dania & 100,0 & 98,4 & 95,6 & 94,6 & 94,6 & 95,6 & 95,6 & 94,0 & 90,0 & 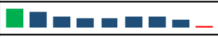 \\
\hline Niemcy & 100,0 & 99,1 & 98,6 & 96,5 & 95,3 & 94,7 & 94,5 & 92,2 & 92,2 & ㅁㅁㅁㅂーーー- \\
\hline Hiszpania & 100,0 & 92,8 & 111,3 & 114,5 & 107,3 & 95,7 & 104,8 & 102,5 & 97,5 & 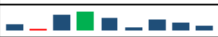 \\
\hline Francja & 100,0 & 101,9 & 106,7 & 114,0 & 114,9 & 117,4 & 120,2 & 121,5 & 123,2 & 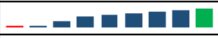 \\
\hline Lotwa & 100,0 & 96,9 & 91,5 & 87,1 & 74,1 & 79,9 & 83,4 & 81,6 & 80,2 & ㅁㅁㅁㅡ-ーーーー \\
\hline Litwa & 100,0 & 100,5 & 97,0 & 90,4 & 72,9 & 71,9 & 73,5 & 73,1 & 77,2 & ㅁㅁㅁㅡ_--- \\
\hline Węgry & 100,0 & 100,5 & 95,7 & 98,5 & 93,3 & 94,3 & 94,3 & 97,9 & 98,4 & 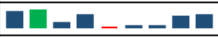 \\
\hline Polska & 100,0 & 98,9 & 96,9 & 97,0 & 89,3 & 84,7 & 81,6 & 80,1 & 80,1 & ㅁㅁㅁㅁ---- \\
\hline Rumunia & 100,0 & 99,3 & 102,9 & 117,5 & 108,4 & 101,2 & 99,7 & 106,5 & 109,4 & -_-口﹎-_E \\
\hline Slowacja & 100,0 & 101,0 & 100,0 & 84,8 & 60,4 & 58,3 & 60,5 & 59,9 & 56,7 & ㅁㅁ믄---- \\
\hline Wielka Brytania & 100,0 & 95,3 & 95,7 & 101,4 & 103,8 & 105,0 & 99,8 & 99,1 & 99,1 & 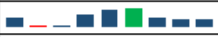 \\
\hline Chorwacja & 100,0 & 103,9 & 111,9 & 120,3 & 101,0 & 96,5 & 92,4 & 95,5 & 103,1 & 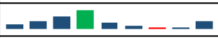 \\
\hline Szwecja & 100,0 & 99,7 & 100,4 & 98,0 & 98,0 & 98,7 & 101,2 & 99,9 & 100,1 & ㅁㅁㅁ﹎._- \\
\hline Razem & 100,0 & 98,6 & 101,6 & 102,9 & 98,9 & 97,0 & 97,3 & 96,5 & 95,9 & 믐ㅁㄴ-ー- \\
\hline
\end{tabular}

Źródło: opracowanie własne, na podstawie danych OECD.

Analizując zebrane dane obejmujące lata 2005-2013 można zauważyć wyraźny spadek wielkości wykonywanej pracy przewozowej (mln pasażerokilometrów) w większości krajów. W analizowanym okresie największą dynamiką charakteryzowała się Francja (wzrost o 23\% w stosunku do roku 2005), oraz Rumunia (wzrost o 9\%). Z grupy 16 analizowanych państw (ograniczenie wymuszone brakiem danych dla pozostałych krajów należących do Wspólnoty) aż dla 11 państw zaobserwowano spadek wykonanej pracy przewozowej, w tym dla Słowacji (niemal o 47\%), Bułgarii (28\%), Litwy (23\%), Łotwy i Polski (po 20\% w stosunku do roku bazowego).

Na rysunku 1 zobrazowano zmianę procentową wykonanej pracy przewozowej w transporcie drogowym wyrażoną w pasażerokilometrach w stosunku do 2008 r. i w kolejnych latach w stosunku do 2008 r. Zaobserwowane zmiany w roku 2009 w stosunku do roku 2008 wskazują na spadek pracy przewozowej wyrażonej w pasażerokilometrach w 10 spośród 16 analizowanych państw. Największy spadek w stosunku do roku poprzedniego odnotowano dla Słowacji (28,8\%), wyraźnie spadła także wykonana praca przewozowa na Litwie, w Bułgarii i na Łotwie. W krajach, w których wykonana praca przewozowa nie spadła, nie można mówić o jej wzroście, a jedynie o utrzymaniu na stałym poziomie. Rok 2009 należał do tych, w którym najbardziej dało się zauważyć skutki kryzysu, w kolejnych latach bowiem obserwowano dalsze spadki wykonanej pracy przewozowej, z tym że były już one rzędu kilku 
procent. Ostatecznie, w 2013 roku w stosunku do roku 2012 jedynie dla sześciu państw zaobserwowano kilkuprocentowy (maksymalny 5,3\%) spadek analizowanego wskaźnika.

Rys. 1. Zmiana procentowa przewozów w pasażerskim transporcie drogowym w kolejnych latach w stosunku do 2008 r. $(2008=100)$

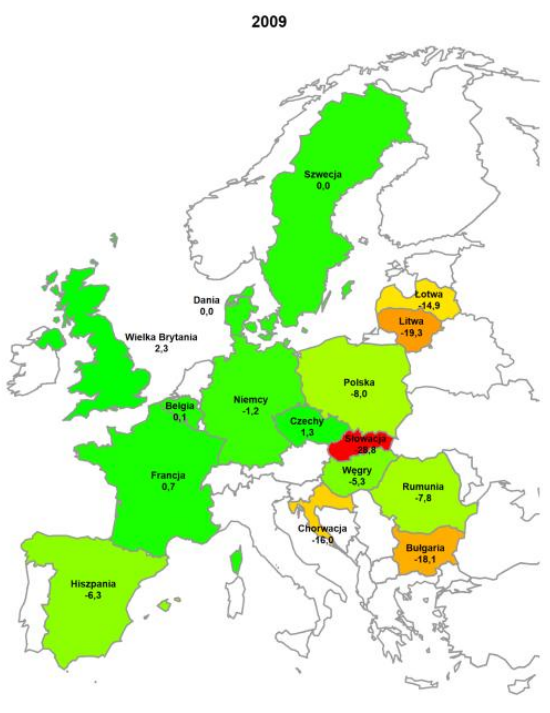

2011

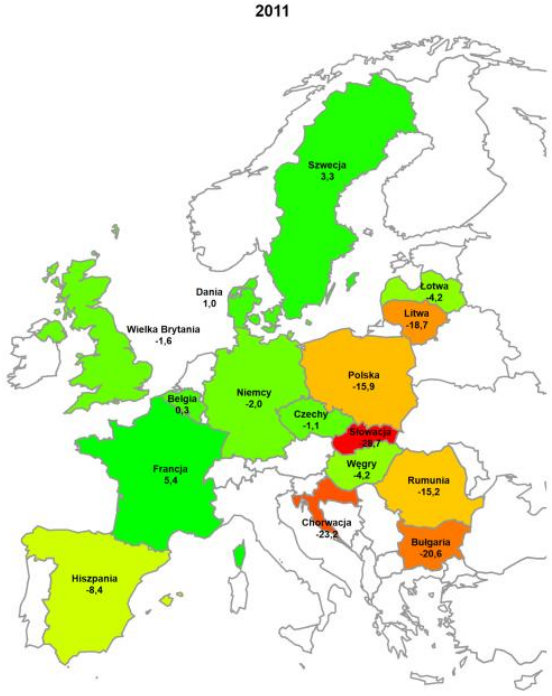

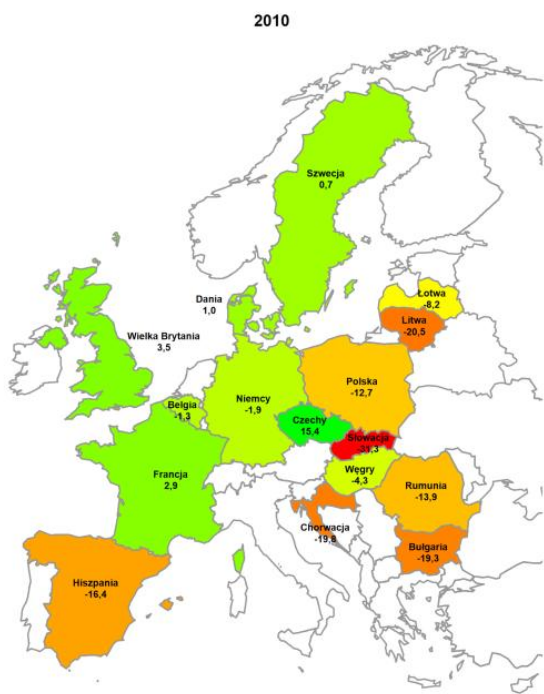

2013

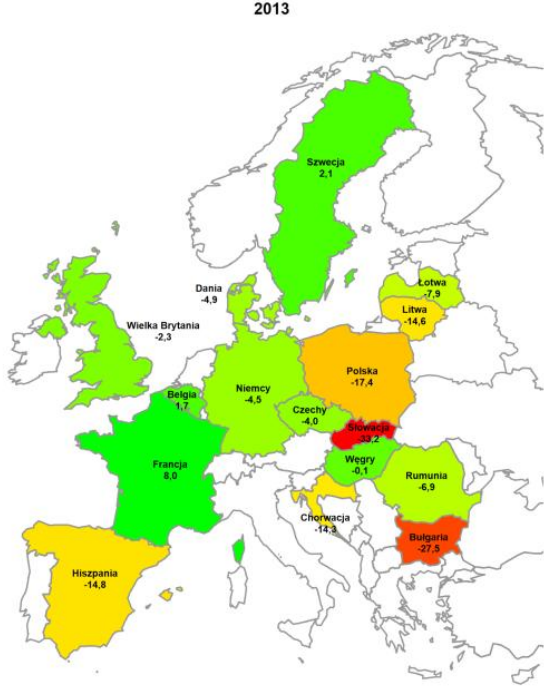

Źródło: opracowanie własne. 
Przedstawione dane wskazują na wyraźny i systematyczny spadek znaczenia drogowego transportu pasażerów w Polsce i w analizowanych krajach Unii Europejskiej. Wielkość popytu na samochodowe przewozy pasażerskie w perspektywie do 2030 r. z pewnością będzie wzrastać wolniej niż PKB czy popyt na drogowy transport towarowy. Można także przypuszczać, że tendencja taka będzie się utrzymywać, a nawet pogkębiać ze względu na wzrost przewozów indywidualnymi środkami transportu. Dlatego tak istotny jest nacisk kładziony na rozwój infrastruktury drogowej i działania mające na celu popularyzację transportu zbiorowego.

\section{ZMIANY PRZEWOZÓW PASAŻERSKIM TRANSPORTEM KOLEJOWYM}

Funkcjonowanie transportu kolejowego opiera się na przewozie ładunków i osób, z wykorzystaniem do tego celu środków transportu kolejowego poruszających się po wydzielonej w tym celu linii kolejowej stanowiącej drogę transportową. Jak pozostałe gałęzie transportu, również transport kolejowy cechują pewne własności stanowiące o jego specyfice.

Jedną $\mathrm{z}$ cech wyróżniających pasażerski transport kolejowy jest zdolność do jednorazowego przewożenia dużej liczby pasażerów, wysoki stopień bezpieczeństwa, niski poziom negatywnych oddziaływań na środowisko naturalne i stosunkowo niski,w stosunku do pozostałych gałęzi transportu, koszt przewozu. Możliwości rozwoju transportu kolejowego są znacznie uzależnione od infrastruktury kolejowej.

W celu skoordynowania działań infrastrukturalnych państw należących do Unii Europejskiej podpisane zostały umowy: European Agreement on Main International Railway Lines (AGC;Europejska Umowa o Głównych Międzynarodowych Liniach Kolejowych) oraz European Agreement on Important International Combined Transport Lines and Related Installations (AGTC;Europejska Umowa o Głównych Liniach i Urządzeniach Transportu Kombinowanego), zakładające między innymi utworzenie na obszarze Unii wspólnej sieci kolejowej oraz zagwarantowanie ujednoliconych parametrów przy budowie, projektowaniu, modernizacji nowych i istniejących linii będących częścią ciągów europejskich ${ }^{7}$.

Dokonując analizy zebranych danych dotyczących lat 2005-2013, można mówić o dość istotnej dynamice zmian $\mathrm{W}$ wykonanej pracy przewozowej pasażerskiego transportu kolejowego (mierzonej w pasażerokilometrach). W 2013 r. w objętych analizą krajach europejskich wykonano pracę przewozową wynoszącą 417,1 mln pasażerokilometrów, co stanowi wzrost w stosunku do 2005 r. o 13,5\%. Do krajów charakteryzujących się największą pracą przewozową w tym samym roku należały: Hiszpania ( $92,4 \mathrm{mln}$ pasażerokilometrów), Niemcy $(86,7 \mathrm{mln}$ pasażerokilometrów), Wielka Brytania (59,1 mln pasażerokilometrów) i Włochy $(52,1 \mathrm{mln}$ pasażerokilometrów). W Polsce natomiast wykonana została praca przewozowa na poziomie $16,8 \mathrm{mln}$ pasażerokilometrów, co stanowi siódme miejsce spośród 25 państw objętych analizą i niestety jest to niższy wynik w stosunku do roku 2005 o 7,5\%. Podobną sytuację można zaobserwować również w 11 państwach, z których największy spadek charakteryzuje Grecję (aż o 60\%), Rumunię (45\%), Chorwację (32\%), Bułgarię (24\%) i Węgry (20\%). Największy wzrost w wielkości wykonanej pracy przewozowej mierzonej

${ }^{7}$ http://wsb.edu.pl/container/Biblioteka\%20WSb/ksi\%C4\%85\%C5\%BCki\%20elektroniczne/ekonomiczne-iorganizacyjne-aspekty-transportu.pdf, s. 47-51. 
w pasażerokilometrach dla transportu koleją zaobserwowano dla Luksemburga i Austrii (40\%),Wielkiej Brytanii (39\%) i Szwecji (32\%). Dynamikę analizowanego wskaźnika w poszczególnych latach w stosunku do 2005 r. przedstawiono w tabl. 2.

Tabl. 2. Dynamika zmian wykonanej pracy przewozowej w transporcie kolejowym wyrażona w pasażerokilometrach w latach 2005-2013

\begin{tabular}{|c|c|c|c|c|c|c|c|c|c|c|}
\hline KRAJ & 2005 & 2006 & 2007 & 2008 & 2009 & 2010 & 2011 & 2012 & 2013 & Wykres zmienności \\
\hline Bulgaria & 100,0 & 101,4 & 101,5 & 97,7 & 89,7 & 87,9 & 86,6 & 78,5 & 76,4 & ㅁㅁㅁㅁㅁㅁㅡ-- \\
\hline Czechy & 100,0 & 103,8 & 103,5 & 102,0 & 97,5 & 98,9 & 100,7 & 109,0 & 114,0 & - $-a---n$ \\
\hline Dania & 100,0 & 102,2 & 103,5 & 105,5 & 103,8 & 107,2 & 112,3 & 114,4 & 115,3 & 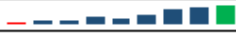 \\
\hline Niemcy & 100,0 & 102,8 & 103,0 & 107,4 & 107,1 & 109,2 & 111,2 & 115,6 & 112,9 & 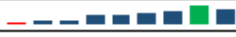 \\
\hline Estonia & 100,0 & 103,6 & 110,5 & 110,5 & 100,4 & 99,6 & 98,0 & 94,8 & 90,7 & 븜ㅁㅁㅁㅁㅂㅡ- \\
\hline Irlandia & 100,0 & 105,1 & 112,7 & 110,9 & 94,5 & 94,2 & 92,0 & 88,6 & 88,1 & 븜ㅁㅁㅁㅡ-ーー \\
\hline Grecja & 100,0 & 97,7 & 104,1 & 89,4 & 76,3 & 72,1 & 51,7 & 44,9 & 40,7 & ㅁㅁㅁㅁㅁㅁㅁ-- \\
\hline Hiszpania & 100,0 & 102,2 & 101,1 & 110,8 & 107,0 & 103,8 & 105,4 & 103,9 & 110,0 & 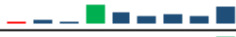 \\
\hline Francja & 100,0 & 104,3 & 107,0 & 113,6 & 112,7 & 112,7 & 116,8 & 116,9 & 121,7 & 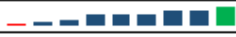 \\
\hline Whochy & 100,0 & 100,2 & 99,4 & 98,9 & 96,1 & 94,2 & 99,8 & 99,8 & 104,1 & 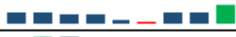 \\
\hline Lotwa & 100,0 & 111,0 & 110,0 & 106,4 & 84,6 & 83,8 & 82,9 & 81,1 & 81,5 & ㅁㅁㅁㅁㅁ---- \\
\hline Litwa & 100,0 & 100,7 & 95,6 & 93,0 & 83,4 & 87,1 & 90,9 & 94,2 & 91,4 & 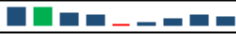 \\
\hline Luksemburg & 100,0 & 109,6 & 116,2 & 126,8 & 122,4 & 127,6 & 128,3 & 137,1 & 141,5 & 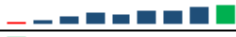 \\
\hline Wegry & 100,0 & 97,0 & 88,6 & 83,9 & 81,7 & 77,9 & 79,0 & 79,0 & 79,4 & 믐-ー-ー- \\
\hline Holandia & 100,0 & 107,9 & 105,5 & 104,0 & 104,5 & 104,5 & 114,1 & 120,6 & 120,0 & 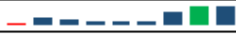 \\
\hline Austria & 100,0 & 109,8 & 113,1 & 127,9 & 125,8 & 126,8 & 128,7 & 133,7 & 140,7 & 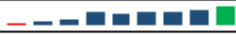 \\
\hline Polska & 100,0 & 102,2 & 109,4 & 111,2 & 102,6 & 98,7 & 100,1 & 98,2 & 92,5 & 붐ㅁㅁー- \\
\hline Portugalia & 100,0 & 103,3 & 106,2 & 112,3 & 110,6 & 109,5 & 110,4 & 101,3 & 97,2 & -ーㅁㅁㅁㅁㅁㄷㅡ. \\
\hline Rumunia & 100,0 & 101,3 & 93,6 & 87,1 & 76,7 & 68,1 & 63,5 & 57,2 & 55,2 & ㅁㅁㅁㅁㅡ-ーー \\
\hline Slowenia & 100,0 & 102,1 & 104,5 & 107,3 & 108,1 & 104,6 & 99,5 & 95,5 & 97,8 & 븜ㅁㅁㅁㅁㅁ-- \\
\hline Slowacja & 100,0 & 101,4 & 99,2 & 105,2 & 103,8 & 105,8 & 111,4 & 112,7 & 113,9 & 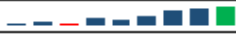 \\
\hline Finlandia & 100,0 & 101,8 & 108,6 & 116,5 & 111,4 & 113,8 & 111,6 & 116,0 & 116,5 & 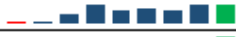 \\
\hline Wielka Brytania & 100,0 & 105,9 & 113,1 & 118,6 & 118,2 & 124,9 & 131,4 & 136,6 & 138,6 & 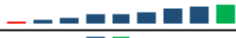 \\
\hline Chorwacja & 100,0 & 107,6 & 127,3 & 143,0 & 144,9 & 137,6 & 117,4 & 87,2 & 67,8 & 붐ㅁㅁㅁㅁㅡ- \\
\hline Szwecja & 100,0 & 107,6 & 114,8 & 124,7 & 126,7 & 124,8 & 127,3 & 132,0 & 132,5 & 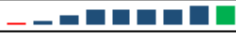 \\
\hline Razem & 100,0 & 103,4 & 105,0 & 108,9 & 106,8 & 107,1 & 110,4 & 112,1 & 113,5 & 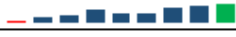 \\
\hline
\end{tabular}

Źródło: opracowanie własne, na podstawie danych OECD.

$\mathrm{Na}$ rysunku 2 przedstawiono wykonaną pracę przewozową $\mathrm{w}$ pasażerskim transporcie kolejowym wyrażoną w pasażerokilometrach w $2008 \mathrm{r}$. i w kolejnych latach w stosunku do tego roku. W analizie zmian w roku 2009 w stosunku do roku 2008 nie jest widoczny wyraźny spadek pracy przewozowej wyrażonej w pasażerokilometrach (jedynie kilka krajów charakteryzuje spadek omawianego wskaźnika). Natomiast wyraźny spadek wykonanej pracy przewozowej rysuje się w latach późniejszych. Największy spadek w stosunku do roku bazowego (2008) zaobserwowano w Grecji w 2013 r. (54,4\%), podobnie w 2008 r. Chorwację charakteryzował wzrost omawianego wskaźnika $(1,4 \%)$, gdy w roku 2013 wartość wskaźnika w ujęciu rok do roku spadła o 52,6\% w porównaniu z rokiem 2008. 
Rys. 2. Zmiana procentowa wykonanej pracy przewozowej w pasażerskim transporcie kolejowym w kolejnych latach w stosunku do 2008 r. $(2008=100)$

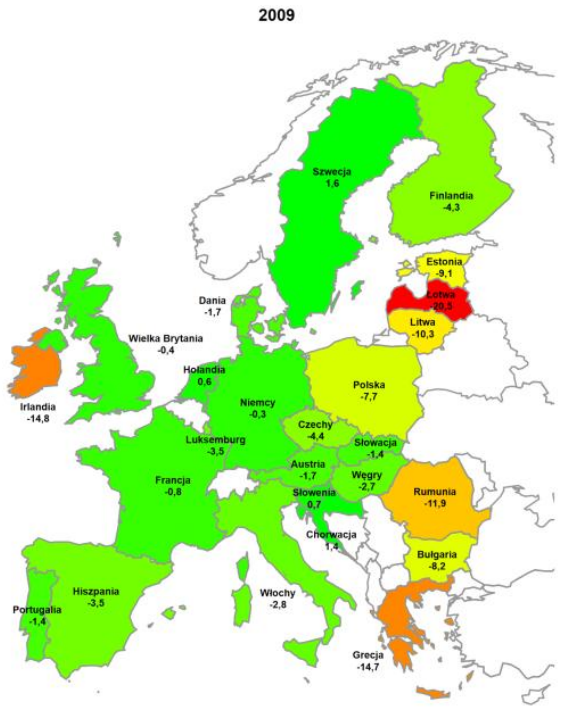

2011

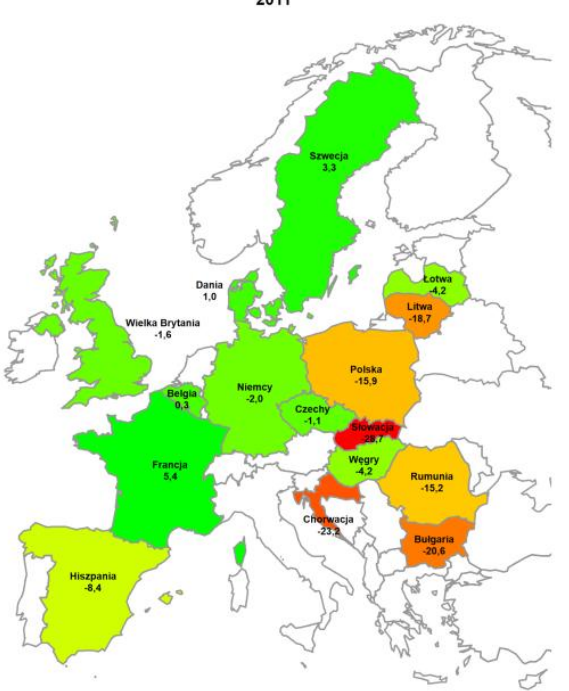

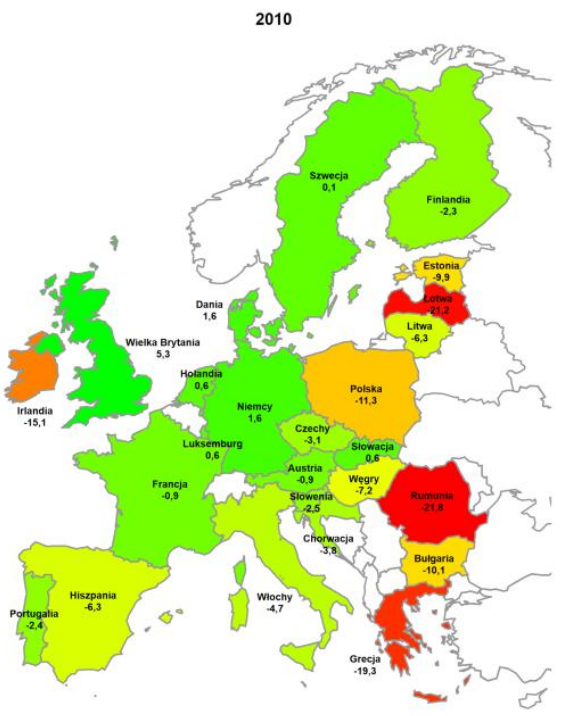

2013

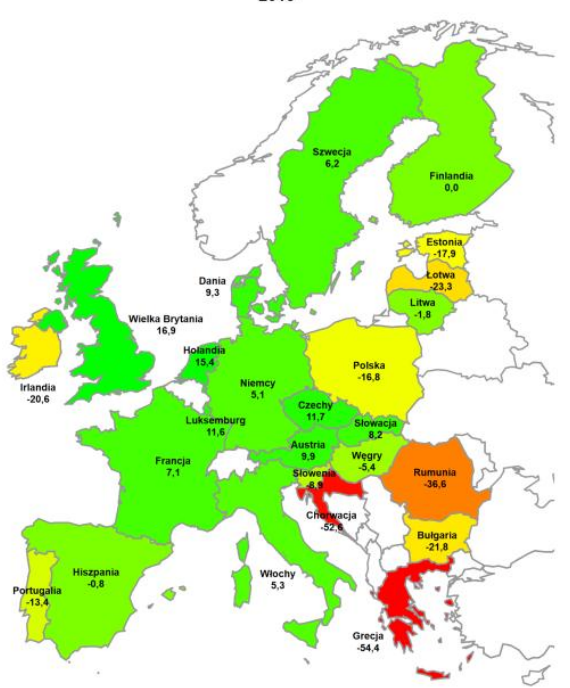

Źródło: opracowanie własne. 
W kilku krajach, między innymi w Polsce, Słowacji, Chorwacji, Estonii, Irlandii czy Bułgarii, widoczny jest stopniowy, ale systematyczny spadek pracy przewozowej dla transportu kolejowego, dzieje się tak z powodu wypierania tej gałęzi transportu między innymi przez transport drogowy.

\section{PASAŻERSKI TRANSPORT LOTNICZY}

Infrastruktura transportu lotniczego pozytywnie wpływa na rozwój gospodarczy i społeczny regionów. Funkcjonowanie portu lotniczego niesie za sobą korzyści dla gospodarki także w wymiarze regionalnym. Nie jest jednak możliwe wykorzystywanie istnienia infrastruktury lotniskowej bez jej właściwego powiązania z układem transportowym pozostałych gałęzi transportu ${ }^{8}$.

W ciągu ostatnich lat znacznie zmienił się system gospodarczy państw, co było efektem kryzysu na rynkach światowych. Jego ogniwem jest także transport lotniczy, który charakteryzuje się podatnością na zmiany w stabilności gospodarki. Osoby prywatne i przedstawiciele firm często są skłonni do rezygnacji z podróży szybkim i wygodnym transportem, jakim jest samolot, w obliczu kryzysu finansowego 9

Po 2004 r. wśród krajów nowo przyjętych do struktur Unii Europejskiej transport lotniczy stał się najszybciej rozwijającą się gałęzią transportu. Wynika to nie tylko ze wzrostu gospodarczego, ale również z powiązanego z nim ogólnego wzrostu mobilności społeczeństw, skłonności do częstszego przemieszczania się. Dużą rolę odgrywają także przewoźnicy, którzy przez poszerzanie swojej oferty (tańsze bilety lotnicze, promocje) w istotny sposób wpływają na wzrost przewozów pasażerskim w transporcie lotniczym ${ }^{10}$.

W 2013 r. z transportu lotniczego, w objętych analizą krajach europejskich (dane dotyczą pasażerskiego transportu lotniczego kraju zgłaszającego), skorzystało 1,2 mld pasażerów, co stanowi wzrost o $20,7 \%$ w stosunku do roku 2005. Krajem odznaczającym się największą liczbą przewiezionych pasażerów w 2013 r. jest Wielka Brytania $(210 \mathrm{mln})$, kolejne miejsca zajmują: Niemcy (180 mln), Hiszpania (157 mln), Francja (138 mln). Polska plasuje się na 13 pozycji wśród analizowanych 25 państw z liczbą 23,3 $\mathrm{mln}$ przewiezionych pasażerów. $\mathrm{W}$ tablicy 3 przedstawiono dynamikę zmian $\mathrm{w}$ przewozach pasażerskich transportem lotniczym w ujęciu przestrzennym.

Z zebranych i opracowanych danych wynika, że krajami o najwyższym przyroście pasażerów w przewozach lotniczych w latach 2005-2013 są: Polska (228\%), Rumunia (187\%), Łotwa (156\%), Litwa (143\%). Wśród państw o najniższym wskaźniku dynamiki w analizowanym okresie należałoby wyróżnić Irlandię (1\%), Słowację i Wielką Brytanię (mimo że jest krajem o najwyższych przewozach pasażerskich transportem lotniczym spośród krajów Unii Europejskiej, 3\%), Słowenię (4\%).

\footnotetext{
${ }^{8}$ M. Śmieszek, A. Migała-Warchoł, G. Mentel, Perspektywy rozwoju transportu lotniczego typu cargo,„Logistyka” 2014/6, s.9685-9686.

${ }^{9} \mathrm{R}$. Rettinger, P. Staszak, Wplyw kryzysu na wielkość pasażerskiego ruchu lotniczego na świecie na podstawie wybranych przykładów, Prace Komisji Geografii Przemysłu, Warszawa-Kraków 2011/18, s. 137.

${ }^{10} \mathrm{http}: / /$ www.siskom.waw.pl/lotnisko_polska.htm.
} 
Wielkość przewozów...

Tabl. 3. Dynamika zmian przewozów pasażerskich w transporcie lotniczym w latach 2005-2013

\begin{tabular}{|c|c|c|c|c|c|c|c|c|c|c|}
\hline KRAJ & 2005 & 2006 & 2007 & 2008 & 2009 & 2010 & 2011 & 2012 & 2013 & Wykres zmienności \\
\hline Belgia & 0,0 & 107,5 & 116,8 & 123,4 & 119,7 & 127,4 & 140,9 & 145,5 & 148,1 & 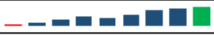 \\
\hline Czechy & 0,0 & 8,0 & 6,3 & 9,2 & 9,8 & 8,7 & S & & & - \\
\hline Dania & 0,0 & 3,6 & 8,4 & 1,1 & 0,5 & 9,7 & & 6 & 3,8 & - - \\
\hline Niemcy & 100,0 & 5,6 & 2,2 & & 08,3 & 113 & & & & - - \\
\hline Estonia & 100,0 & 10,1 & 23,6 & 29 & 96,3 & 99,1 & 1 & 1 & & 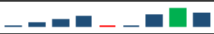 \\
\hline Irlandia & 100,0 & 113,6 & 23,0 & 23,8 & 108,3 & 95,2 & 96,3 & 97,3 & & - \\
\hline Grecja & 100,0 & 106,4 & 112,9 & 11,7 & 106,8 & 104,3 & 108 & 102 & 2 & - $=010$. \\
\hline Hiszpania & 100,0 & 104,8 & 113,8 & 12,3 & 103,2 & 106,8 & 114,9 & 2 & 8 & - \\
\hline Francja & 100,0 & 104,8 & 11,2 & 13,7 & 108,9 & 113,8 & 121 & 1 & 9 & 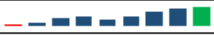 \\
\hline Wlochy & 100,0 & 109,1 & 20,9 & 19,7 & 115,8 & 124,1 & 132 & 0 & 1 & - \\
\hline Cypr & 100,0 & 99,0 & 103,3 & 06,4 & 99,2 & 102 & 106 & 0 & 4 & 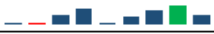 \\
\hline Lotwa & 100,0 & 132,9 & 168,6 & 97,0 & 217 & 248 & 272 & 254 & 5 & 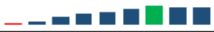 \\
\hline Litwa & 100,0 & 125,4 & 153,1 & 177,9 & 130 , & 159 & 187 & 220 & 8 & - - \\
\hline Luksemburg & 100,0 & 103,9 & 106,3 & 111,4 & 99. & 104 & 119 & 1 & 0 & $---ー--\operatorname{an}$ \\
\hline Węgry & 100,0 & 104,1 & 108,4 & 106, & 102 & 103 & 112 & 5 & 6 & - - \\
\hline Malta & 100,0 & 97,9 & 107,8 & 112, & 105, & 119 & 127 & 4 & 2 & -ーー・ーロ日日 \\
\hline Holandia & 100,0 & 104,6 & 108,8 & 108 , & 100 & 104 & 116 & 119 & 1 & 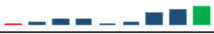 \\
\hline Austria & 100,0 & 105,8 & 116 & 121, & 110 & 119 & 127 & 13 & 130 & $--=$ \\
\hline Polska & 100,0 & 194,0 & 241,8 & 264, & 240, & 259,6 & 291 & 307 & 328,7 & $-=$ \\
\hline Portugalia & 100,0 & 108,7 & 120,0 & 124,2 & 118, & 126 & 136 & 139 & 146,5 & $--=$ \\
\hline Rumunia & 100,0 & 140,3 & 197,7 & 229,9 & 228,5 & 253 & 277,3 & 276,9 & 286,7 & --5 \\
\hline Slowenia & 100,0 & 109,1 & 123,6 & 135,5 & 116,9 & 113 & 111 & 96,0 & 04,0 & _- \\
\hline Slowacja & 100,0 & 139,8 & 146, & & 128 & & & & & $-\mathbf{n}$ \\
\hline Finlan & 100,0 & 1( & & & & 115,2 & & 133,3 & 34,2 & 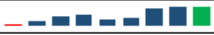 \\
\hline Wielka Brytania & 100,0 & 103,5 & 106,5 & 104 & 97,3 & 94,5 & 98,8 & 99,5 & 103,2 & 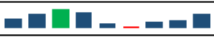 \\
\hline Razem & 100,0 & 106,5 & 113,9 & 114,6 & 107,4 & 110,5 & 117,8 & 118,5 & 120,7 & 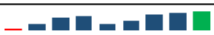 \\
\hline
\end{tabular}

Źródło: opracowanie własne, na podstawie danych Eurostat.

Na rysunku 3 przedstawiono zmianę procentową liczby pasażerów transportu lotniczego w kolejnych latach po kryzysie w odniesieniu do 2008 r. Analiza zebranych danych daje wyraźny obraz wpływu kryzysu na wielkość przewozów pasażerskich tą gałęzią transportu, jest to jednak zmiana dotycząca tak naprawdę tylko jednego roku (2009 w stosunku do 2008). Największy spadek przewozów w 2009 r. w stosunku do roku poprzedniego zaobserwowano dla Estonii, Litwy i Słowacji (25\%), zaskoczeniem jest pozycja Łotwy, w której jako jedynej spośród analizowanych krajów w tym samym roku odnotowano wzrost (10\%). W Polsce, podobnie jak w pozostałych krajach, zaobserwowano niewielki spadek wielkości przewozów w stosunku do roku poprzedniego (9\%), z tym że w kolejnych latach w tym samym ujęciu (w stosunku do roku 2008) widoczny jest ciągły wzrost pasażerskich przewozów transportem lotniczym. 
Rys. 3. Zmiana procentowa liczby pasażerów w transporcie lotniczym w kolejnych latach w stosunku do 2008 r. $(2008=100)$

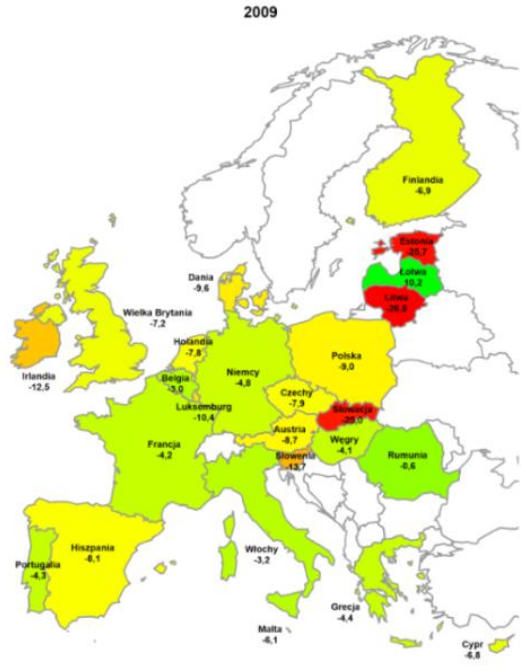

2011

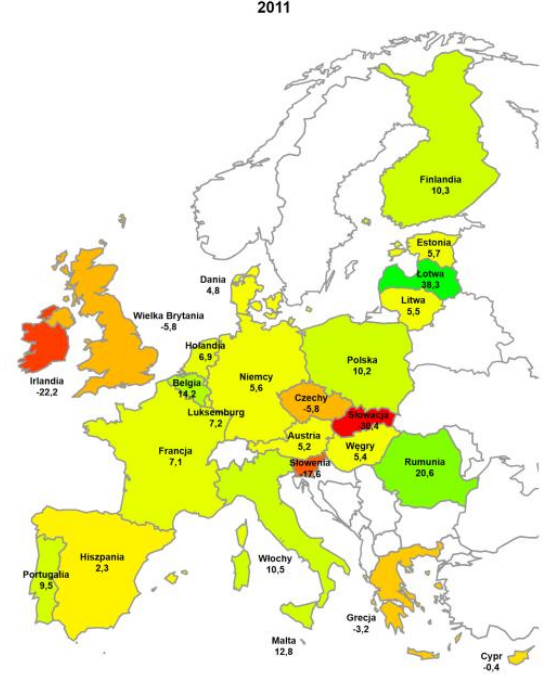

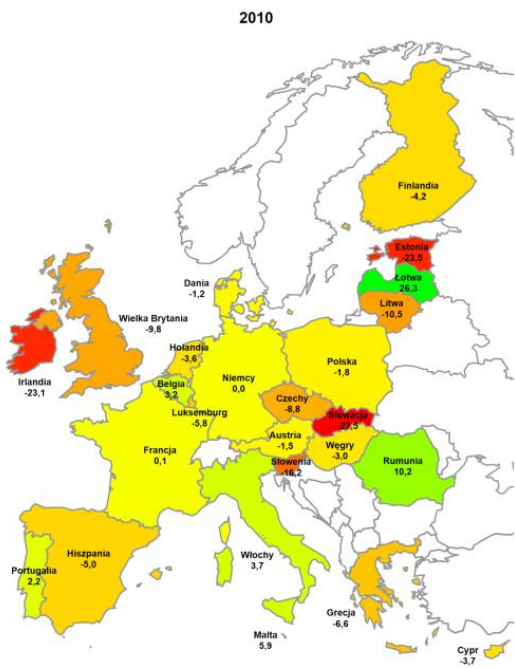

2013

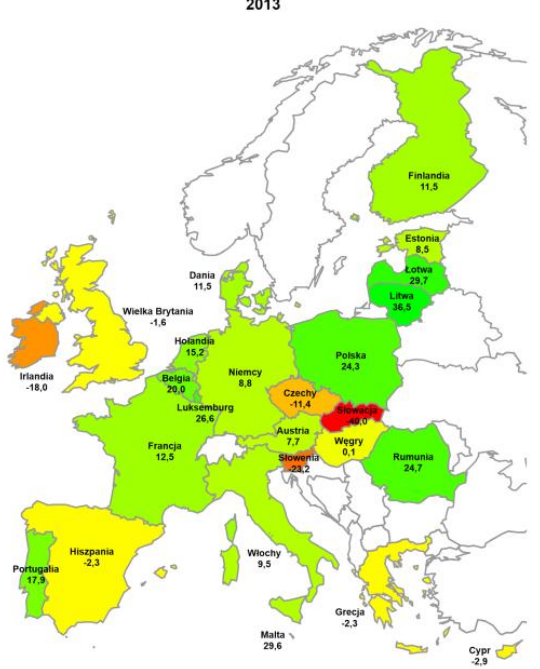

Źródło: opracowanie własne. 
Wielkość przewozów...

Rys. 4. Wskaźnik liczby pasażerów transportu lotniczego do liczby mieszkańców krajów dla 2013r.

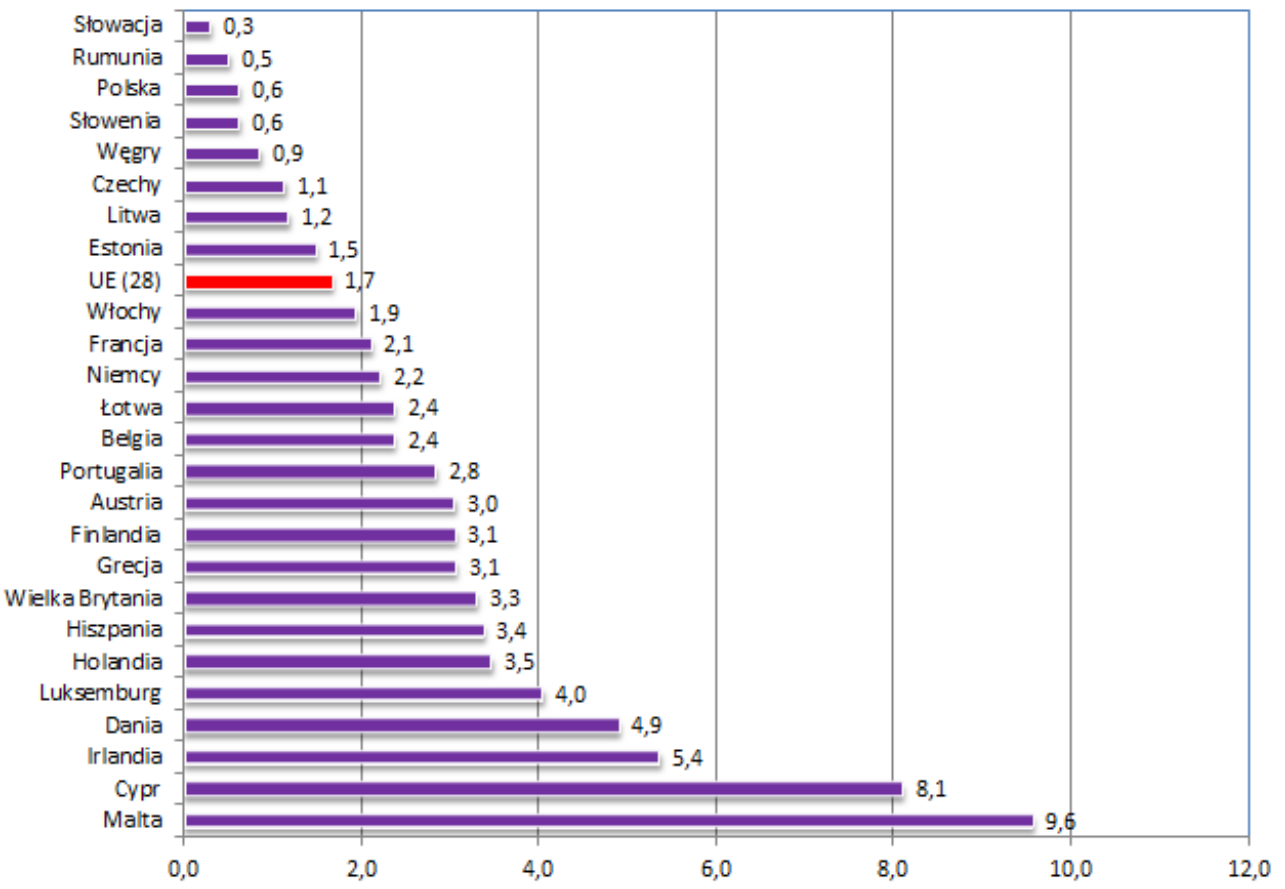

Tak więc większości krajów europejskich bardzo szybko udało się odbudowała pozycję do stanu sprzed kryzysu pod względem wielkości lotniczych przewozów pasażerskich. Jedynie Słowacji, Słowenii, Irlandii, Czechom, Wielkiej Brytanii, Cyprowi, Grecji i Hiszpanii nie udało się odbudować poziomu wielkości przewozów w stosunku do roku 2008, nawet w 2013 r. (rys. 4).

5. ZMIANA POZIOMU PRZEWOZÓW PASAŻERSKICH W ODNIESIENIU DO WSKAŹNIKA MOTORYZACJI

Wskaźnik motoryzacji stanowi jedną z miar statystycznych, wykorzystywaną do oceny stanu transportu na określonym obszarze (miasto, region czy kraj), w tym przypadku kraj. Przez wskaźnik motoryzacji określa się liczbę samochodów osobowych przypadających na tysiąc mieszkańców.

Wśród krajów europejskich największą wartością wskaźnika charakteryzuje się Luksemburg (661samochodów osobowych na 1000 mieszkańców), Litwa (615), Włochy (608) i Cypr (591). O ile wysoki wskaźnik motoryzacji w małych państwach nie musi dziwić, o tyle w tych większych może budzić zaskoczenie. Polska znajduje się na 10. miejscu spośród analizowanych państw, z liczbą 510 samochodów osobowych na 1000 mieszkańców, co oznacza że pod względem zmotoryzowania, statystycznie nasz kraj nie ustępuje potęgom 
gospodarczym, takim jak Japonia czy Stany Zjednoczone. Oznacza to także, że na dwóch mieszkańców Polski przypada jeden samochód osobowy.

Analizując dynamikę zmian w obrębie wskaźnika motoryzacji przedstawioną na rysunku 5, w grupie wybranych państw europejskich, w 2013 r. Polska zajęła pierwsze miejsce pod tym względem (wzrost o 58\% w stosunku do roku 2005). Duży wzrost odnotowały także takie kraje jak Rumunia (51\%), Słowacja (43\%), Litwa (39\%). Jedynie w Łotwie, Wielkiej Brytanii i w Niemczech zaobserwowano spadek analizowanego wskaźnika w latach (2005-2013).

Rys. 5. Wskaźnik motoryzacji- liczba samochodów osobowych przypadająca na 1000 mieszkańców w wybranych krajach Unii Europejskiej w 2005 i 2013 r.
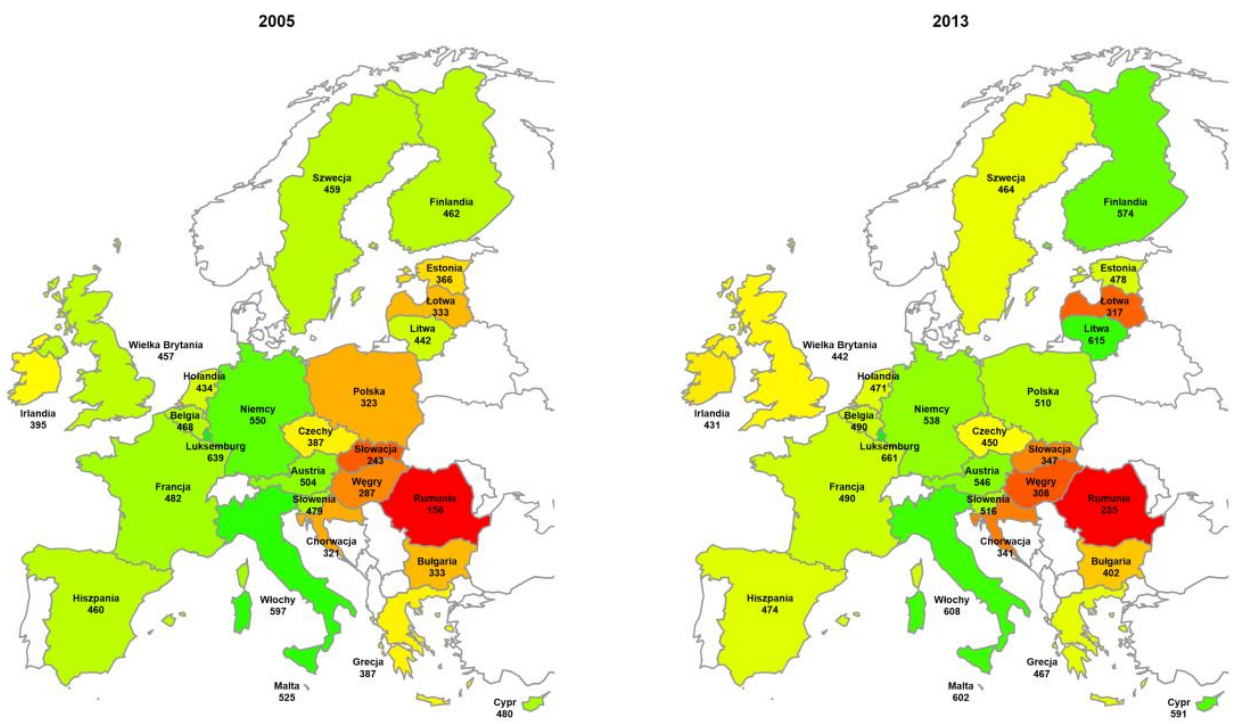

Źródło: opracowanie własne.

Zatem w kwestii stopnia nasycenia rynku samochodami osobowymi Polska osiągnęła już dawno średnią unijną. Nadmienić jednak należy, że pewna część tych pojazdów dawno zniknęła z dróg, ale ciągle jest zarejestrowana w systemie CEPIK. Niepokojący jest także wiek samochodów poruszających się po polskich drogach, nawet Bułgarzy czy Rumunii bowiem jeżdżą samochodami zdecydowanie „młodszymi” niż Polacy. Znacznie większe zainteresowanie starszymi samochodami nastąpiło po 2004 r., zatem po przystąpieniu do Unii Europejskiej, co wynika ze zniesienia niemal wszystkich ograniczeń dotyczących importu używanych samochodów. Zazwyczaj rozwój gospodarki jest powiązany ze wzrostem sprzedaży nowych samochodów, w Polsce sytuacja ma się jednak inaczej, co nie zmienia faktu, że stopień zmotoryzowania społeczeństwa jest pośrednim miernikiem zarówno rozwoju gospodarczego, jak i społecznego państwa. 
Relacja między poziomem zmian w wykonanej pracy przewozowej dla kolejowego i drogowego transportu pasażerskiego a wartością wskaźnika zmotoryzowania społeczeństwa może pozwalać badać zmianę w poziomie i stylu życia mieszkańców analizowanych państw europejskich.

Rys. 6. Dynamika wskaźnika motoryzacji w relacji do dynamiki przewozów pasażerskich transportem kolejowym i drogowym w wybranych krajach Unii Europejskiej (porównanie 2005 i 2013 r.)

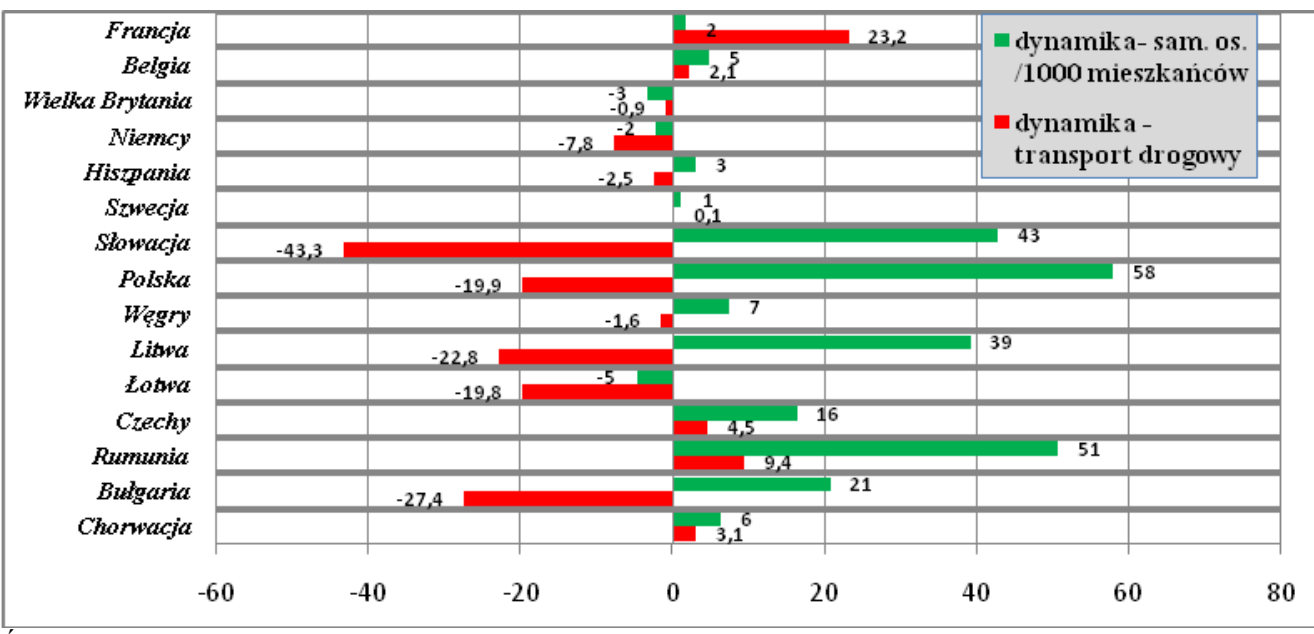

Źródło: opracowanie własne

Dokonując porównania dynamiki wzrostu wskaźnika motoryzacji w relacji do zmian w obrębie pasażerskiego transportu drogowego i kolejowego (mierzonego wykonana pracą przewozową -wyrażoną w pasażerokilometrach), przedstawionej na rysunku 6, widoczne jest wyraźne zróżnicowanie między tymi krajami. Analizując Polskę, widać wzrost wskaźnika motoryzacji o 58\% (największy wzrost) i spadek pasażerskich przewozów transportem kolejowym o $7,5 \%$, a drogowym niemal o $20 \%$. W przypadku Niemiec te same wskaźniki kształtują się w relacji $-2 \%, 12,9 \%$ i $-7,8 \%$. Krajem o największym wzroście przewozów drogowym transportem pasażerskim w analizowanym okresie jest Francja (23\%), przy jednoczesnym wzroście wskaźnika motoryzacji o 2\% i wzroście kolejowych przewozów pasażerskich o $21,7 \%$.

Wśród nowych państw europejskich (należących do struktur Unii Europejskiej po 2004 r.) widoczny jest zdecydowanie większy wzrost wskaźnika motoryzacji, a zatem indywidualnego transportu.

\section{PODSUMOWANIE}

W większości krajów europejskich odnotowuje się spadek wielkości przewozów pasażerskich (mierzony wykonaną pracą przewozową) w transporcie drogowym. W wypadku pasażerskiego transportu kolejowego można mówić o pewnym wzroście 
przewozów. Wolno rozwijający się popyt na drogowe przewozy pasażerskie jest wynikiem istnienia silnego substytutu, jaki stanowi transport indywidualny, wywołujący dodatkowo zagęszczenie ruchu w sieci drogowej (kongestię).

Wskaźnik motoryzacji mierzony liczbą samochodów przypadających na tysiąc mieszkańców analizowanego kraju zdecydowanie wzrasta. I tak jak w przypadku przewozów pasażerskich obserwowana jest wyraźna tendencja spadkowa, to w przypadku wskaźnika motoryzacji można mówić o dynamicznym wzroście liczby pojazdów osobowych. Polska należy do krajów, w których wzrost w badanym okresie (2005-2013) jest największy.

Analizowane wskaźniki sytuacji na rynku transportowym wskazują, że o ile w wypadku pasażerskiego transportu lotniczego, w obrębie wszystkich państw objętych analizą, można mówić o chwilowym (jednorocznym) wpływie kryzysu na przewozy, o tyle w transporcie drogowym odnotowuje się spadek wielkości przewozów, w transporcie kolejowym zaś systematyczny, stabilny, kilkuprocentowy wzrost z roku na rok. W wypadku transportu lotniczego można mówić o wpływie kryzysu, natomiast w przypadku transportu drogowego i kolejowego większy wpływ niż kryzys może mieć wpływ wzrostu wskaźnika mobilności, a zatem liczby samochodów osobowych. Jednak w obrębie poszczególnych krajów relacje te kształtują się zupełnie odmiennie.

Można stwierdzić, że cały widoczny wzrost mobilności społeczeństwa w Polsce i w krajach europejskich został wchłonięty przez indywidualny transport, choć na uwagę zasługuje także pasażerski transport lotniczy, którego wielkość przewozów wyraźnie wzrasta, w porównaniu z przewozami koleją czy publicznym transportem drogowym.

\section{LITERATURA}

[1] Grad B., Krajewska R., Wpływ kryzysu na przewozy pasażerów transportem kolejowym w krajach Unii Europejskiej, „Logistyka” 2011/3, s. 765-766.

[2] Hajdul M., Stajniak M., Foltyński M., KolińskiA., Andrzejczyk P., Organizacja i monitorowanie procesów transportowych, Poznań 2015.

[3] Januła E., Podstawy transportu i spedycji. A. 28. Organizacja i nadzorowanie transportu. 1. Planowanie realizacji procesów transportowych, Warszawa 2014.

[4] Polski rynek ushug transportowych. Funkcjonowanie - przemiany - rozwój, red. D. Rucińska, Warszawa 2012.

[5] Rettinger R., Staszak P., Wptyw kryzysu na wielkość pasażerskiego ruchu lotniczego na świecie na podstawie wybranych przykładów, Prace Komisji Geografii Przemysłu, Warszawa-Kraków 2011/18.

[6] Śmieszek M., Migała-Warchoł A., Mentel G., Perspektywy rozwoju transportu lotniczego typu cargo, „Logistyka” 2014/6, s.9685-9686.

[7] http://www.siskom.waw.pl/lotnisko_polska.htm.

[8] http://wsb.edu.pl/container/Biblioteka\%20WSb/ksi\%C4\%85\%C5\%BCki\%20ele ktroniczne/ekonomiczne-i-organizacyjne-aspekty-transportu.pdf, s. 47-51. 


\section{SIZE OF PASSENGER TRANSPORT IN RELATION TO THE AUTOMOTIVE INDICATOR IN SELECTED COUNTRIES OF EUROPEAN UNION IN THE YEARS} 2008-2013

Complex and multifaceted economic system of today's world is a very sensitive system of collective functional and system connections. As a result of the outcomes of economic crisisare experienced in different parts of the world and economic sectors of human activity. Monitoring of changes in the economy, especially during the crisis, is important to identify the causes of its origin, and in the next stage, to find solutions enabling effective mitigation of the consequences of its occurrence. Contemporary societies tend to increasing mobility and the goal of European Union policy is to develop and support efficient, safe and sustainable solutions which provide it. Passenger transport is of great importanceand it indicates the transport needs reflecting the wellbeing of the society and the economic condition of the state.

The study compares the size of the transport performance in passenger transport by road and rail and the number of passengers carried by air transport. For the analysis the variable, which is also the number of registered passenger cars per thousand inhabitants in selected countries of the European Union, has been applied. The analysis aims to identify: differentiation between passenger transport by various modes and an assessment of the impact of the economic crisis of 2008 on the size of the analyzed transport in EU. An additional objective of the study was to present the Polish position against other countries, and an indication of relationships of an increase in the number of registered passenger cars to the size of the passenger. The publication has been based on the data presented by Eurostat and the OECD.

Keywords: economic crisis, passenger transport, the rate of motorization.

DOI:10.7862/rz.2016.hss.27

Przesłano do redakcji: styczeń 2016

Przyjęto do druku: lipiec 2016 